Professor Timotej JAGRIC, PhD, CQRM, Head of Institute of Finance and Banking, Faculty of Economics and Business University of Maribor, Slovenia

E-mail: timotej.jagric@um.si

Professor Stefan BOJNEC, Head of Department of Economics

Faculty of Management, University of Primorska, Slovenia

E-mail stefan.bojnec@fm-kp.si

Doc.Vita JAGRIC,PhD, Department of Finance(Corresponding author)

Faculty of Economics and Business, University of Maribor, Slovenia

E-mail: vita.jagric@um.si

\title{
A MAP OF THE EUROPEAN INSURANCE SECTOR - ARE THERE ANY BORDERS?
}

Abstract. Our paper studies the challenge of the EU single insurance market. We analyse a sample of 23 European countries' insurance industries (EU and non-EU members) for the 2003-2012 period. With a dynamic analysis we try to discover whether the EU's insurance industry is homogeneous and converging via the EU integration process, but diverging from non-EU markets. Our findings support the rejection of the set hypothesis, when analysing the high dimensional insurance industry data with a method from the neural networks family. While four groups of European countries are identified, none of the clusters can be considered as part of EU mainstream. In addition to the EU integration process, there may be some other factors that influence the economic performance and fragmentation of the European insurance industry and the country's relative position within the European insurance market on dynamic topographic maps. The EU policy makers ought to further strengthen the integration process in the insurance market.

Key words: insurance industry, convergence, divergence, neural networks, Single Market, big data analysis.

\section{JEL Classification: C45, F15, F36, G22}

\section{Introduction}

The insurance industry is facing global challenges due to the changing economic environment, changing landscape of risks and uncertainties, insurance regulations, and new, emerging challenges. The reserve and capital regulations are changing from traditional to principle-based approaches. These factors may contribute to the global convergence of insurance products (Clark, 2009). 
Timotej Jagric, Stefan Bojnec, Vita Jagric

Along with global factors, national ones influence the insurance market heavily: including legislation and the economic growth rate or a slowdown (Sangowski, 2002, in Bernat and Grundey, 2007). Additional determinants of changes in the insurance markets include the prescription of obligatory insurance by the government, the introduction of a substitution product like pension schemes (funds), as well as social and psychological factors like the insurance consciousness level (Sulkowska, 2000, in Bernat and Grundey, 2007, and Handschke, 2004 in Bernat and Grundey, 2007).

The European insurance market accounts for 33 per cent of market share on a global scale and European insurers play an important role in the global insurance market, since five out of nine global systemically important insurers are European companies (European Commission 2014, p. 52). In the European Union (EU), financial integration is closely monitored and analysed as part of the Single European Market (SEM), therefore a deeper integration on the insurance market within the SEM is expected. In this paper we are only interested in the insurance market in Europe, leaving out segments of banking integration and capital market integration. The impact of progressive liberalization, integration and development of the SEM and the whole European insurance market has motivated several studies (Müller-Reichart, 2005, Fenn et al., 2008, Kasman and Turgutlu, 2011, Apergis, et al. 2012, Cummins et al. 2017).

The main goal of the present analysis is to study the set hypothesis on the homogeneity of the insurance industry in Europe. The estimation of the degree of the homogeneity was studied with regard to the aggregate features of the national insurance market in the 2003-2012 period. A major advantage of this study is not only the relatively long time period of the analysis but especially a wide range of included European countries. The results of the study are obtained with a new methodology, which was already successfully applied for studying banking sector features. This will enable us to appropriately compare both financial industries in Europe in the future and their dynamics in-depth.

The rest of the article is structured as follows. First, we give an overview of the European Insurance Market as reported in existing literature. In the third section we describe the data basis which was used in this study and the rationale for the chosen methodology of the research. Next we turn to a presentation of the results and an analysis of them. After this, we provide a discussion of the study results. In the end we summarize our results in the conclusion.

\section{The European Insurance Market}

In the EU the path towards the SEM for Insurance began as early as 1973 with the First Non-Life Insurance Directive (Kasman and Turgutlu, 2011). Together with the following insurance directives, all of them aimed to remove barriers towards the integrated insurance market for both non-life and life insurance (Kasman and Turgutlu, 2011). Consolidation in the European insurance market through mergers and acquisition has been taking place, which has been facilitated by the liberalized 
A Map of the European Insurance Sector - Are There any Borders?

insurance market in the EU and may also partly be a response of the insurance companies, which may use scale economies to become a source of efficiency (Fenn et al., 2008).

However, in Europe, the national insurance markets of the countries differ substantially in insurance penetration. As seen in Müller-Reichart (2005) when 10 new member states entered the EU in 2004, the insurance premiums in the old states in the year 2004 amount to a total of 9 per cent of gross domestic product (GDP) compared to only 3 per cent in the accession countries. Müller-Reichart (2005) therefore has seen in 2005 a great potential for growth with eastward EU enlargement and orientation. In 2007 Bernat and Grundey empirically tested the market maturity (as long-term stabilization in reference to perfect competition) of the insurance markets in two new member states (Poland and Lithuania) when comparing them to the old EU-15, referred to as "mature" markets. They found the tested markets to be relatively immature and therefore to be treated as emerging markets. Despite the gap between new member states and the old ones when comparing the gross premium, Müller-Reichart (2005) sees the need of the EU to put in place regulations on the insurance sector so that growth may be realized in both areas: among new and old member states. Unfortunately, the financial crisis has deeply changed the perceived outlook of the pre-crisis period. Consequently, in 2012, the gross written premiums in the EU remain much lower when compared to 2007 (European Commission 2014, p. 52).

When examining the European countries in 2012, the average gross written premiums in that year were 7.6 per cent of GDP, amounting to 4.5 per cent for life insurance and 3.12 per cent for non-life insurance, according to data by Insurance Europe $(2014 \mathrm{~b}$, p. 17). In the same year, negative growth in the gross written premiums between the years 2008 and 2011 was finally turned around (European Commission 2014, p. 52). There are substantial disparities across the observed countries. When omitting Lichtenstein, as the data includes cross-border business, the next highest are the premium volume in the United Kingdom (UK) and the Netherlands at levels close to 12.5 per cent of GDP (Insurance Europe 2014b, p. 17). States with above-average premiums as a percentage of GDP are Finland (for which this data source includes pension funds), Switzerland, France, Denmark, and Belgium. Very close to the average are Germany (including "Pensionskassen" and pension funds), Italy, Portugal, Ireland and Sweden. Just below 6 per cent of GDP are Slovenia and Estonia, followed by Austria, Cyprus, and Norway. The lowest is the level for Romania (1.3 per cent) and Latvia (0.9 per cent) (Insurance Europe 2014b, p. 17).

Differences across countries may also be analysed when measuring the cost inefficiencies of insurance companies. Fenn et al. (2008) noticed that differences across countries are more evident in the life insurance sector. On the other hand, with regard to a cross-country comparison for scale economies among insurance 
Timotej Jagric, Stefan Bojnec, Vita Jagric

companies, Kasman and Turgutlu (2011) noted that countries do not significantly differ from each other.

Another aspect of the insurance market analysis includes the question of profitability, cost efficiency and scale economies of insurance companies. The European Commission (2014, p. 52) reported for the year 2012 that the unweighted return on equity (ROE) for all listed European insurance companies was 8.2 per cent. Fenn et al. (2008) analysed European insurance companies in the 1995-2001 period. When comparing specialized companies (life or non-life) to composite ones, they found that the latter group of companies appear to have a low degree of $\mathrm{X}$-inefficiency, while they found strong evidence that the $\mathrm{X}$-inefficiency of specialist insurers increases with firm size and domestic market share. Kasman and Turgutlu (2011) analysed the cost efficiency of insurance companies in the 19952005 period, including in the EU-15, four new member states and Turkey. Their results indicate that for all analysed countries, their insurance industries are operating off the cost frontier. Additionally, the authors noted that the insurance industries suffered from significant cost inefficiency (Kasman and Turgutlu, 2011).

Insurance sector development, however, has not been unaffected by macroeconomic developments. Low economic growth and high unemployment in the EU have in the 2012-2013 period negatively affected the demand for both life and non-life insurance products (European Commission 2014, p. 51). Additionally, the profitability of insurers was under pressure due to low interest rates and other macroeconomic factors (European Commission 2014, 51).

Financial integration is of keen interest to European policy makers (e.g. European Commission, 2014, European Central Bank, 2014), while the benefits of financial integration on economic growth, capital allocation, the effectiveness of financial markets and many more have been well known in literature and to policymakers (e.g. Adam et al., 2002, Baele et al., 2004, Baltzer et al., 2008, Lane, 2008, Babecký et al., 2010, European Central Bank, 2005 or newer, European Commission, 2009 or newer).

Financial integration refers to multiple segments of the financial markets, and by far the most attention is given to the segment for banking integration and the integration of capital markets. However, there is no reason for insurance sector integration to be given less attention. Apergis et al. (2012) addresses the question of insurance market integration with an investigation of the factors behind the long-term convergence in the insurance industry. They investigated the convergence in the financial ratio in a sample of 16 European insurance companies in the 1990-2010 period. The study by Apergis et al. (2012) provides evidence of limited convergence for the analysed sample when analysing the convergence coefficient and using the Phillips and Sul (2007, in Apergis et al. 2012) log t-test. The results indicate the highest divergence in the investment-to-assets ratio and the 
A Map of the European Insurance Sector - Are There any Borders?

lowest gross profits-to-assets ratio. The resulting limited convergence may be seen as the impact of the prevailing macroeconomic conditions and the state of the economy, conditions on the financial markets and the management preferences of selected insurance companies (Apergis et al., 2012).

The insurance markets of EU members are expected to be strongly supported by the European Insurance and Occupational Pensions Authority (EIOPA), established in 2011, because of the reforming supervisory structure of the EU financial sector. The work of EIOPA will impact the ability of further integration of the European insurance market. EIOPA works in several areas, across its strategic goals, among others: to enhance the transparency, simplicity and many other factors of insurance products across the internal market, to contribute to the development of regulations and supervision of the insurance and occupational pensions market, to contribute to the financial stability of the two sectors (EIOPA 2015, p. 14).

\section{The Analysed Sample and Variables}

In this study, we analysed data for 23 European (both, EU and non-EU) national insurance markets in the 2003-2012 period. A wider range of countries was initially taken into account, but due to substantial missing data in the database in the final sample, a narrower list of countries was maintained. This decision was a trade-off between a wider sample of countries and a greater number of possible variables to be included. We decided for the latter, since the omitted variables could have retained important information. The number of countries included in the sample is still large and includes the following 23 countries: Austria, Belgium, Switzerland, the Czech Republic, Germany, Estonia, Spain, Finland, France, Greece, Croatia, Italy, Luxembourg, Latvia, Malta, the Netherlands, Norway, Poland, Portugal, Romania, Slovenia, Turkey and the United Kingdom (UK). The data source of the statistical series is the Insurance Europe (2014a) database, which reports for its database that industry data for most countries is based on samples representing more than 90 per cent of the insurance market. There are some exceptions, including the following: The data for Romania represents around 70 per cent of the market. The Slovenian data only refers to insurance association members. However, the number of companies includes all of them. There is a break in the time series for Malta from 2008 onwards, since prior to 2008 the data included cross-border business. The data for Portugal includes workers' compensation in the accident branch (Insurance Europe 2014a).

Insurance industry data for each country is described by 21 variables. The list of the variables is presented in Table 1. The first group of variables includes data on premiums, which was gathered (X1-X16). The data on premiums is of two types: density (in EUR per capita) and penetration (ratio premium to GDP). The data on premiums is given on multiple levels of aggregation, the highest level representing 
Timotej Jagric, Stefan Bojnec, Vita Jagric

the total, the medium level being the division into life and non-life insurance, and at the lowest level there are some special types of insurance. The second group of variables is data on the investment portfolio of the insurer (X17-X19), all as a share of GDP. In the third group of variables there are various characteristics of insurance companies in the national market presented, like the number of them, or the number of employees. In order to compare markets of very different sizes, the data in this group is given per capita.

Table 1: List of the variables

\begin{tabular}{|l|l|l|l|}
\hline X01 & Density: Average total premiums per capita & X12 & Density: Average property premiums per capita \\
\hline X02 & Penetration: Total premiums to GDP ratio & X13 & Penetration: Property premiums to GDP ratio \\
\hline X03 & Density: Average life premiums per capita & X14 & Density: Average general liability premiums per capita \\
\hline X04 & Penetration: Life premiums to GDP ratio & X15 & Penetration: General liability premiums to GDP ratio \\
\hline X05 & Density: Average non-life premiums per capita & X16 & Insurers' investment portfolio to GDP ratio \\
\hline X06 & Penetration: Non-life premiums to GDP ratio & X17 & Non-life insurers' investment portfolio as the share in GDP \\
\hline X07 & Density:Average total motor premiums per capita & X18 & Life insurers' investment portfolio as the share in GDP \\
\hline X08 & Penetration: Total motor premiums to GDP ratio & X19 & Number of companies operating on the market per capita \\
\hline X09 & Density: Average health premiums per capita & X20 & Number of licensed life insurance companies per capita \\
\hline X10 & Density: Average accident premiums per capita & X21 & Number of insurance company employees \\
\hline X11 & Penetration: Accident premiums to GDP ratio & & \\
\hline
\end{tabular}

The industry data formed an unbalanced panel, in that all variables do not include data for the whole analysed 2003-2012 period for all countries. The source of the data is the database by Insurance Europe (2014a). The database by Insurance Europe is, according to Insurance Europe (2014), mostly based on annual data, which is collected from their member associations. Data on European insurance groups was collected by Insurance Europe (2014a) from l'Argus de l'Assurance. Macroeconomic data, i.e. for population, GDP and exchange rates, was (2014a) taken by Insurance Europe from Eurostat - the Statistical Office of the European Communities, and from national statistical offices.

In the database by Insurance Europe (2014a) the euro was used as a monetary unit for all financial data. For countries that are not a part of the Eurozone, the data was converted into Euros by Insurance Europe (2014a) using the yearly average exchange rate. Additionally, for Eurozone members for the periods prior to the introduction of the euro, the Insurance Europe (2014a) has converted the data. As this data is given in real terms in the Insurance Europe's database, we have deflated the following variables: X01, X03, X05, X07, X09, X10, X12, and X14. The data on premiums from the Insurance Europe's database entail gross written premiums (direct business) on home territory underwritten by companies with their head office (Insurance Europe 2014a). 
A Map of the European Insurance Sector - Are There any Borders?

Table 2: Statistical analysis of the data

\begin{tabular}{|c|c|c|c|c|c|c|c|c|c|c|c|}
\hline & Mean & Media & Max & Min & Std. D. & Skew. & Kurtosis & $\mathrm{JB}$ & Prob. & Sum & Sum Sq. D. \\
\hline $\mathrm{X} 01$ & 0.9549 & 0.8699 & 3.4404 & 0.0135 & 0.8281 & 0.8020 & 2.9294 & 25.3456 & 0.000 & 225.352 & 161.1537 \\
\hline $\mathrm{X} 02$ & 0.7365 & 0.6799 & 2.0272 & 0.1112 & 0.4344 & 0.5058 & 2.5195 & 12.3350 & 0.002 & 173.819 & 44.3456 \\
\hline $\mathrm{X} 03$ & 0.9074 & 0.7921 & 4.1718 & 0.0038 & 0.8650 & 0.9187 & 3.2397 & 33.7626 & 0.000 & 214.147 & 175.8244 \\
\hline $\mathrm{X} 04$ & 0.6737 & 0.5645 & 2.6613 & 0.0202 & 0.5262 & 0.8118 & 3.2773 & 26.6762 & 0.000 & 158.991 & 65.0752 \\
\hline $\mathrm{X} 05$ & 1.0367 & 0.9080 & 4.8734 & 0.0254 & 0.9769 & 1.8793 & 7.2952 & 320.3223 & 0.000 & 244.653 & 224.2672 \\
\hline X06 & 0.8388 & 0.7348 & 3.0671 & 0.2236 & 0.4841 & 2.3538 & 11.0187 & 850.2095 & 0.000 & 197.955 & 55.0733 \\
\hline $\mathrm{X} 07$ & 1.0593 & 1.0775 & 3.0778 & 0.0500 & 0.6981 & 0.8712 & 3.7134 & 34.8605 & 0.000 & 249.999 & 114.5331 \\
\hline $\mathrm{X} 08$ & 0.9870 & 1.0309 & 1.6495 & 0.4124 & 0.2538 & 0.2025 & 3.3125 & 2.5728 & 0.276 & 232.938 & 15.1353 \\
\hline X09 & 1.2653 & 0.2890 & 15.921 & 0.0009 & 2.9976 & 3.7701 & 16.7284 & 2412.351 & 0.000 & 298.604 & 2111.5500 \\
\hline $\mathrm{X} 10$ & 1.1896 & 0.8863 & 6.0912 & 0.0112 & 1.3752 & 1.6220 & 5.1643 & 149.5449 & 0.000 & 280.742 & 444.4015 \\
\hline $\mathrm{X} 11$ & 0.8926 & 0.6790 & 2.8395 & 0.0412 & 0.7874 & 0.8358 & 2.5979 & 29.0685 & 0.000 & 210.658 & 145.6818 \\
\hline $\mathrm{X} 12$ & 0.9419 & 0.6890 & 3.4698 & 0.0168 & 0.7987 & 0.9961 & 3.3817 & 40.4586 & 0.000 & 222.289 & 149.8950 \\
\hline $\mathrm{X} 13$ & 0.7737 & 0.6897 & 1.7241 & 0.1724 & 0.3553 & 0.5127 & 2.4952 & 12.8464 & 0.002 & 182.586 & 29.6719 \\
\hline $\mathrm{X} 14$ & 1.0433 & 0.6779 & 10.198 & 0.0134 & 1.4555 & 3.5662 & 19.8209 & 3282.516 & 0.000 & 246.210 & 497.8666 \\
\hline $\mathrm{X} 15$ & 0.7180 & 0.5752 & 3.0973 & 0.0442 & 0.5696 & 1.3973 & 5.6467 & 145.6740 & 0.000 & 169.446 & 76.2474 \\
\hline $\mathrm{X} 16$ & 0.7565 & 0.5566 & 5.1253 & 0.0075 & 0.7999 & 2.3068 & 11.0695 & 849.6214 & 0.000 & 178.531 & 150.3561 \\
\hline $\mathrm{X} 17$ & 0.7481 & 0.5680 & 2.8908 & 0.0005 & 0.6997 & 1.5837 & 4.7370 & 128.3268 & 0.000 & 176.551 & 115.0598 \\
\hline $\mathrm{X} 18$ & 0.7671 & 0.5360 & 5.9936 & 0.0006 & 0.9207 & 2.6220 & 12.5875 & 1174.301 & 0.000 & 181.037 & 199.2224 \\
\hline $\mathrm{X} 19$ & 2.3583 & 0.9573 & 23.180 & 0.0799 & 4.6667 & 3.4480 & 13.8120 & 1617.135 & 0.000 & 556.555 & 5117.7940 \\
\hline $\mathrm{X} 20$ & 3.5241 & 1.2883 & 55.991 & 0.1336 & 9.5580 & 4.4283 & 21.3156 & 4070.005 & 0.000 & 831.683 & 21468.3600 \\
\hline $\mathrm{X} 21$ & 1.2609 & 1.1085 & 4.0497 & 0.0935 & 0.8992 & 1.5306 & 5.1345 & 136.9543 & 0.000 & 297.583 & 190.0189 \\
\hline \multicolumn{2}{|c|}{ Observations } & 236 & & & & & & & & & \\
\hline
\end{tabular}

In Table 2 we show the statistical analysis of the data. There is only one variable (X08) which seems to have a distribution close to normal distribution. Non-normal distribution of almost all used variables does not affect the analysis, since the chosen methodology does not imply the assumption of a normal distribution. From the correlation matrix we see a very high degree of correlation between all pairs of variables (the table can be sent to an interested reader). Before the application of the neural networks approach, a data transformation step was conducted. All variables were rescaled into the interval $[0,1]$. This was done because of the properties of the method, as further explained in the next section.

\section{Methodology of the Research}

The methodology of this study was chosen based on the goal of the undertaken research, which was to analyse a wide sample of national insurance markets. When including a large number of variables this leads to a high dimensional input space. In this study the input space consists of vectors, so that each vector represents data for a selected country and a selected year. The chosen method has to be capable of dealing with high dimensional data, which in our case is also an unbalanced panel. Neural networks are a wide range of methods, which satisfy the set conditions.

We used the optimized spiral spherical SOM (OSS-SOM), a method introduced by Jagric (2013). This method overcomes a common problem in the application of 
Timotej Jagric, Stefan Bojnec, Vita Jagric

self-organizing maps, namely the border effect (Jagric and Zunko, 2013). Additionally, this method was applied in the financial research area, for the dynamic analysis of banking sector integration (Jagric, Bojnec and Jagric, 2015), where it was stated that this methodology is particularly suitable for high dimensional data input spaces (big data). Other favourable characteristics of OSSSOM are the capability of handling outliers, the suitability of unbalanced panel data and resilience towards problems of multicollinearity (Jagric, Bojnec and Jagric 2015). As already pointed out by Jagric, Bojnec and Jagric (2015), data describing financial markets and institutions typically do not follow a normal distribution, while it speaks for the choice of the OSS-SOM use since it does not assume the normal distribution of the used data. When compared to the named banking study, in this study we have changed the use of the methodology in order to achieve a way of hierarchical clustering. In doing so, we enhanced the possibilities of the interpretation of the obtained results.

\section{Figure 1: OSS-SOM FOR THE INSURANCE SECTOR IN THE EU: FRONT SIDE OF THE SPHERE (LEFT) AND BACK SIDE OF THE SPHERE (RIGHT)}
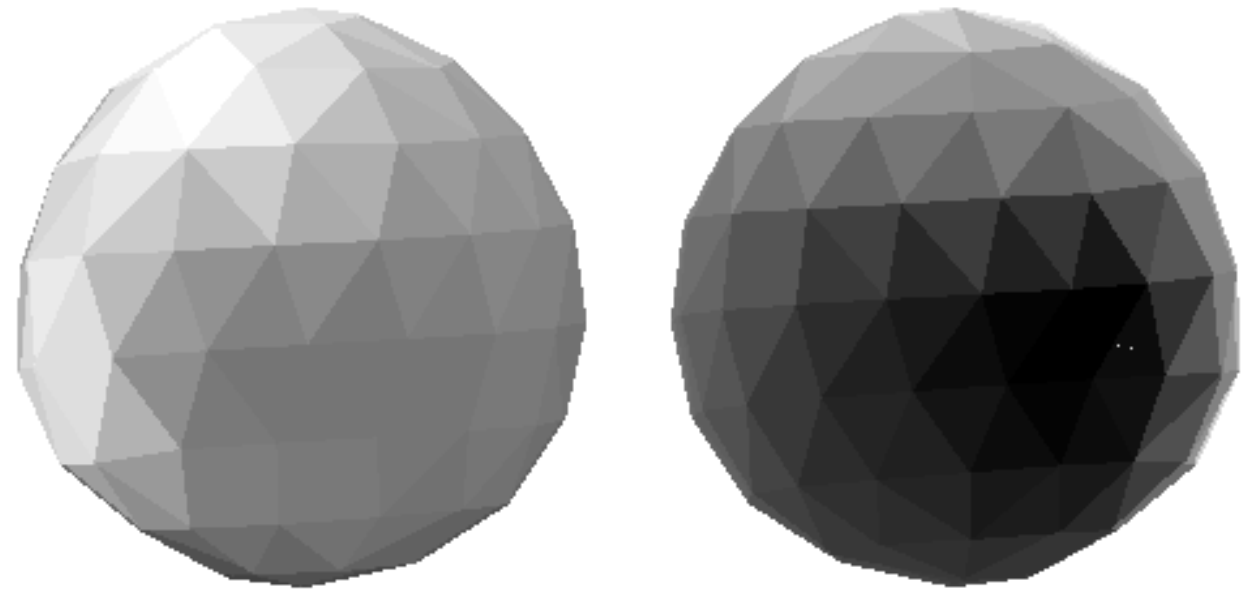

Note: Size of the OSS-SOM is 100 neurons.

The hierarchical OSS-SOM is applied as follows. First, a very low number of neurons is chosen. We have selected the number 4 . In the next step the number of neurons is 10 and in the third it is 50 . At the fourth stage, we reach the final size of the network, which is 100 neurons. In Figure 1 we present the front and back side of the sphere. These gradually bigger sizes will enable us to follow the process of division of bigger clusters into small clusters: the sub-clusters. In financial research the dynamics are especially important for the value of the obtained results. In the analysis of the results we will see how this affects the present study results for the insurance market. 
A Map of the European Insurance Sector - Are There any Borders?

\section{4. $\quad$ Results}

The results, which we obtained with the estimation of the OSS-SOM model, had to be transformed into a planar projection in order to allow for an interpretation of the data. We applied a special procedure for detecting similarities among neighbouring neurons that takes into consideration the deformations of the sphere (Jagric and Zunko, 2013). The obtained projection is shown in Figures 2 and 3, where the first figure is shown as a three dimensional topology, and the next figure is shown as a two dimensional topology. Additionally, in the second one the dynamism of the surface is shown with contour lines.

\section{Figure 2: $\quad 3 D$ PROJECTION OF THE RESULTS - TOPOLOGY OF THE INSURANCE SECTOR}

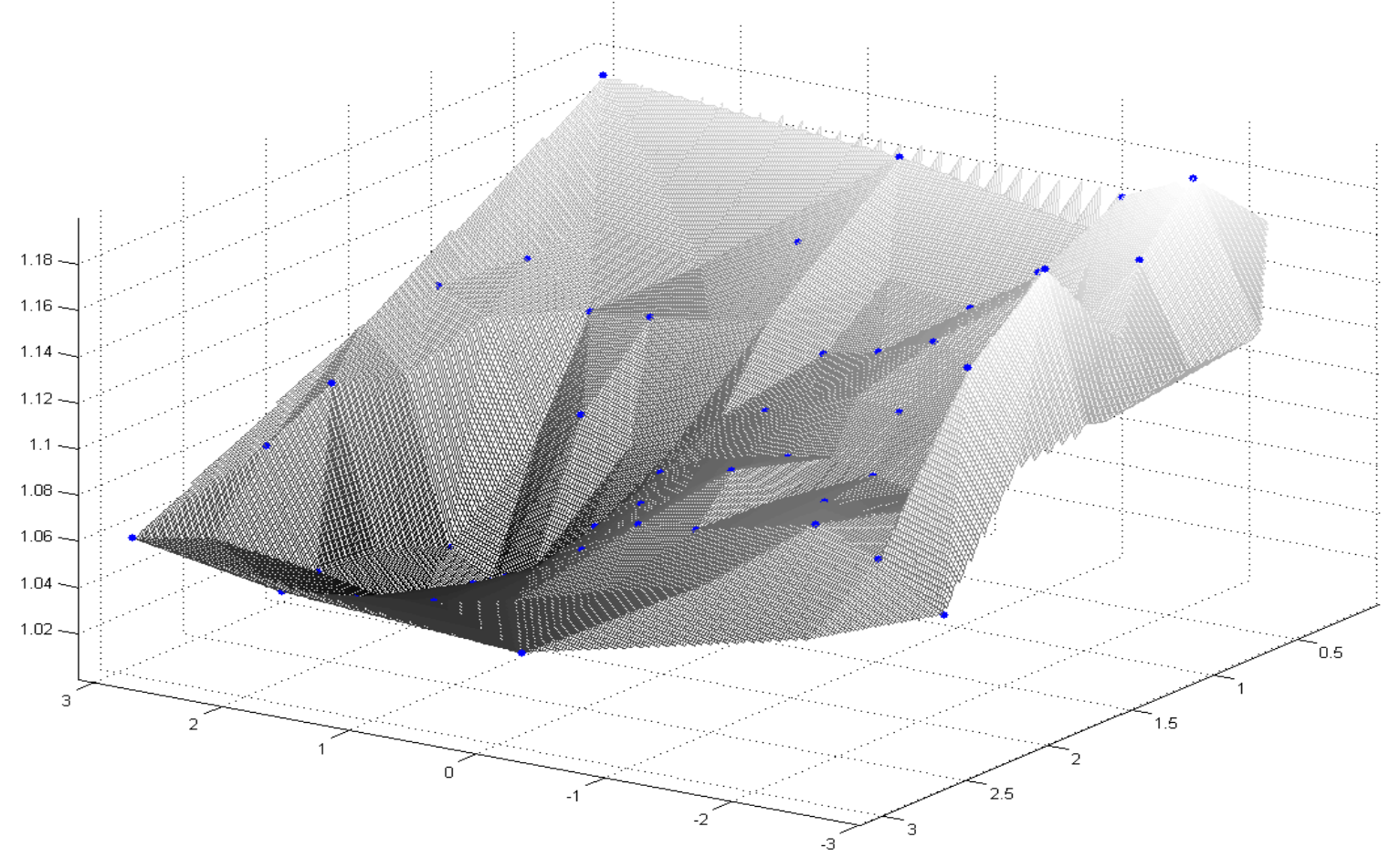

Note: Size of the OSS-SOM - 100 neurons.

On Figure 2 we can discover two dominating elements of the map: one being the ridge and the other being the basin. This fact may be interpreted as two areas, which importantly differ from each other in their features. In-between there are areas which gradually become different and share some feature with other entities. Taking this into account, we may now turn to Figure 3, where we can identify the following countries being in the basin of our map: Romania, Latvia, Turkey, 
Timotej Jagric, Stefan Bojnec, Vita Jagric

Greece, Estonia and Poland. Just next to this area, on the edge, the next group of countries can be found. These are: Croatia, Malta, the Czech Republic, Spain and Norway (but the latter only for the year 2008). Then there is the sloping area which separates the area of the basin and the ridge, where we can find the following countries: Germany, Norway (the remaining years except for 2008), Italy, Portugal, Austria, Slovenia, Finland, France and Belgium. And finally, there are countries which are placed on the ridge of the sphere surface, these being Switzerland, the Netherlands, Luxembourg and the UK.

Figure 3: $\quad$ 2D DYNAMIC PROJECTION OF THE RESULTS TOPOLOGY OF THE INSURANCE SECTOR

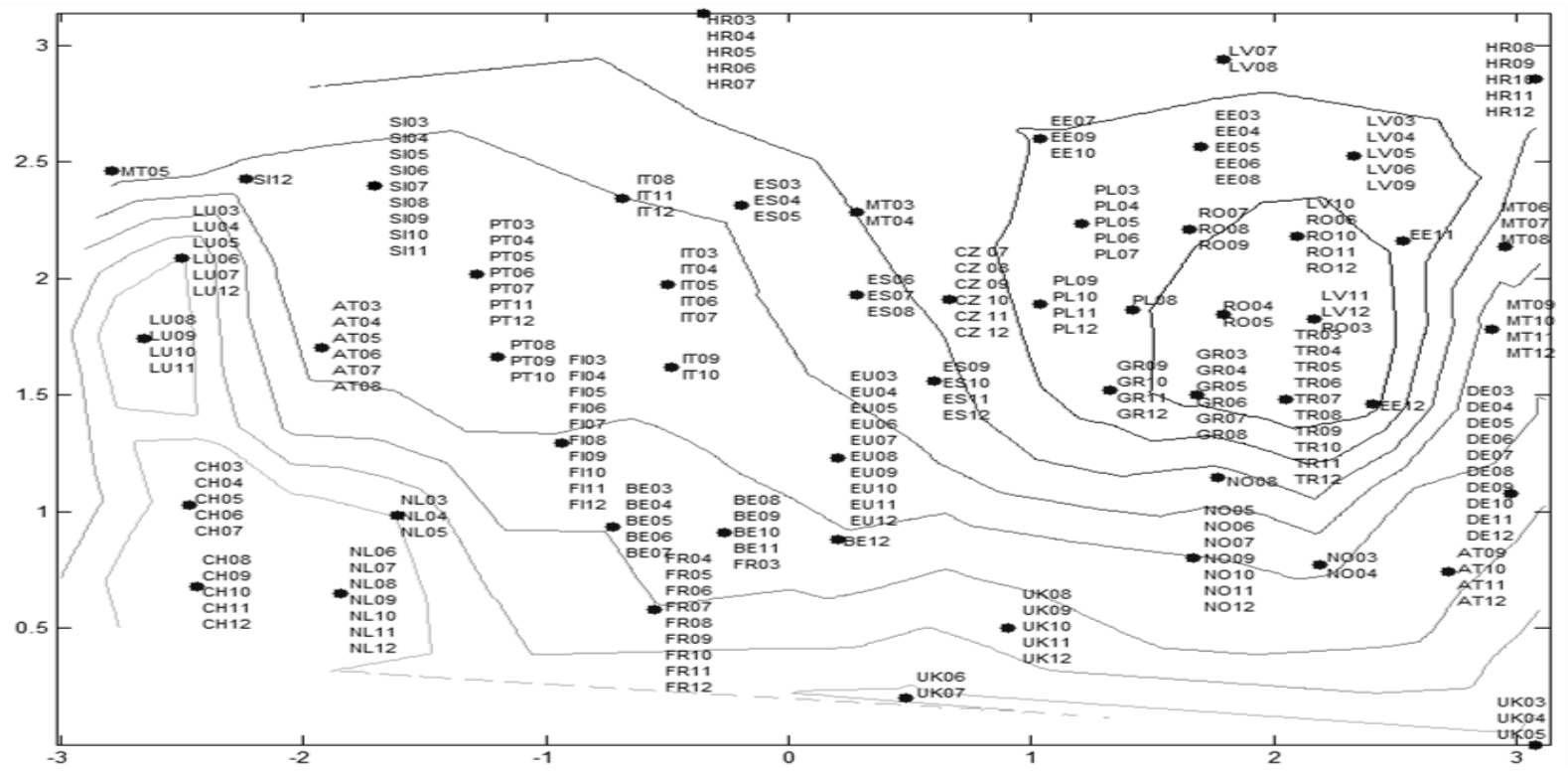

Note: Size of the OSS-SOM - 100 neurons. Labelling - first two characters represent the country code, and the last two the year.

On Figure 3 we can see that in the observed 2003-2012 period, some countries changed their position on the map. However, there are some countries, which in the whole period do not move out of their position, which means that the insurance industry in the analysed countries did not substantially change their features. These countries are Germany, Finland and Turkey, together with the Czech Republic (for which we have data only for the 2007-2012 period). Next, there are countries that only made 1 switch in their position on the map during the observed period: France, Slovenia, Switzerland, the Netherlands, Luxembourg, Austria, Croatia and Greece. Other countries have changed their position's ins and outs several times. 
A Map of the European Insurance Sector - Are There any Borders?

As we have already explained in the previous section, we have estimated more than one model. Next to the above-analysed map of the 100 neurons size, we also obtained results from the lower size maps (with 4, 10 and 50 neurons) as found in Figure 4. The aim of analysing and for comparisons of all obtained results is to trace back the decomposition of larger groups of countries into sub-clusters. With this step we excluded the chance that we have imposed the number of clusters into the model and thus into the final results, which would be very likely in the case of smaller sized maps. And so the analyses may be relying on false interpretation of the data and results. On the other hand, models with larger resolutions allow groups of countries to get isolated from each other and in this way form clear borders between them. Additionally, only higher resolution maps allow for the efficient treatment of outliers, which are less or not at all affecting the position of other countries.

\section{Figure 4: COMPARATIVE RESULTS OF DIFFERENT SIZED NETWORKS}
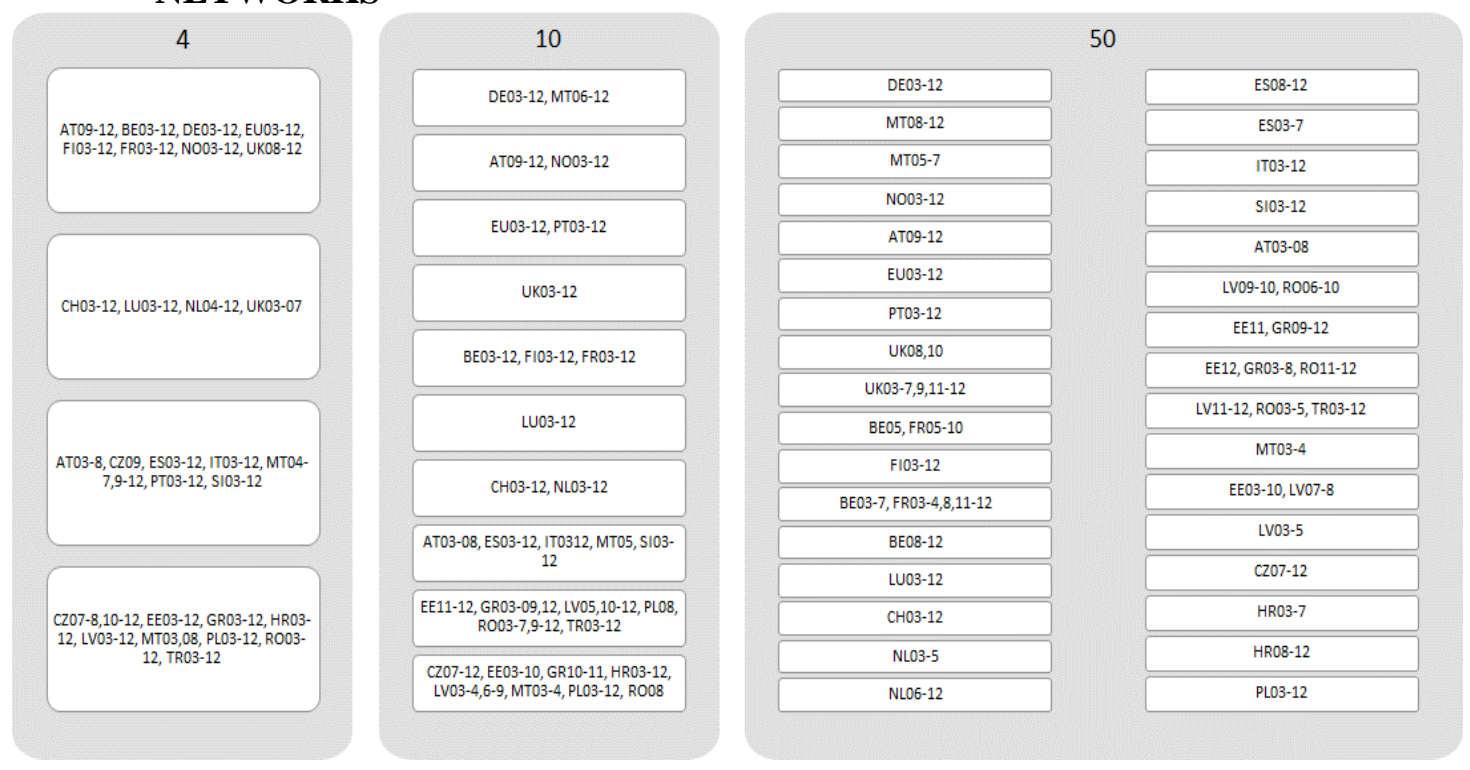

When analysing the results from the lower sized maps, the most interesting thing appears to be the smallest: the map with the 4 neurons. On this map, all four neurons have been winning neurons for some input vectors, so none are left to be empty. The first group of countries are Switzerland, Luxembourg, the Netherlands (for the years 2004-2012, where we separately give the information of included years, since they do not include the whole observed period), and the UK (20032007). The second group of countries consists of Austria (2009-2012), Belgium, Germany, Finland, France, Norway, and the UK (2008-2012). The third group of countries is made up of Austria (2003-2008), the Czech Republic (2009), Spain, Malta (2004-2007, 2009-2012), Portugal, and Slovenia. The last group includes the 
Timotej Jagric, Stefan Bojnec, Vita Jagric

Czech Republic (2007-2008, 2010-2012), Estonia, Greece, Croatia, Lithuania, Malta (2003, 2008), Poland, Romania and Turkey.

Figure 5: $\quad$ HISTOGRAM OF NEURON HITS

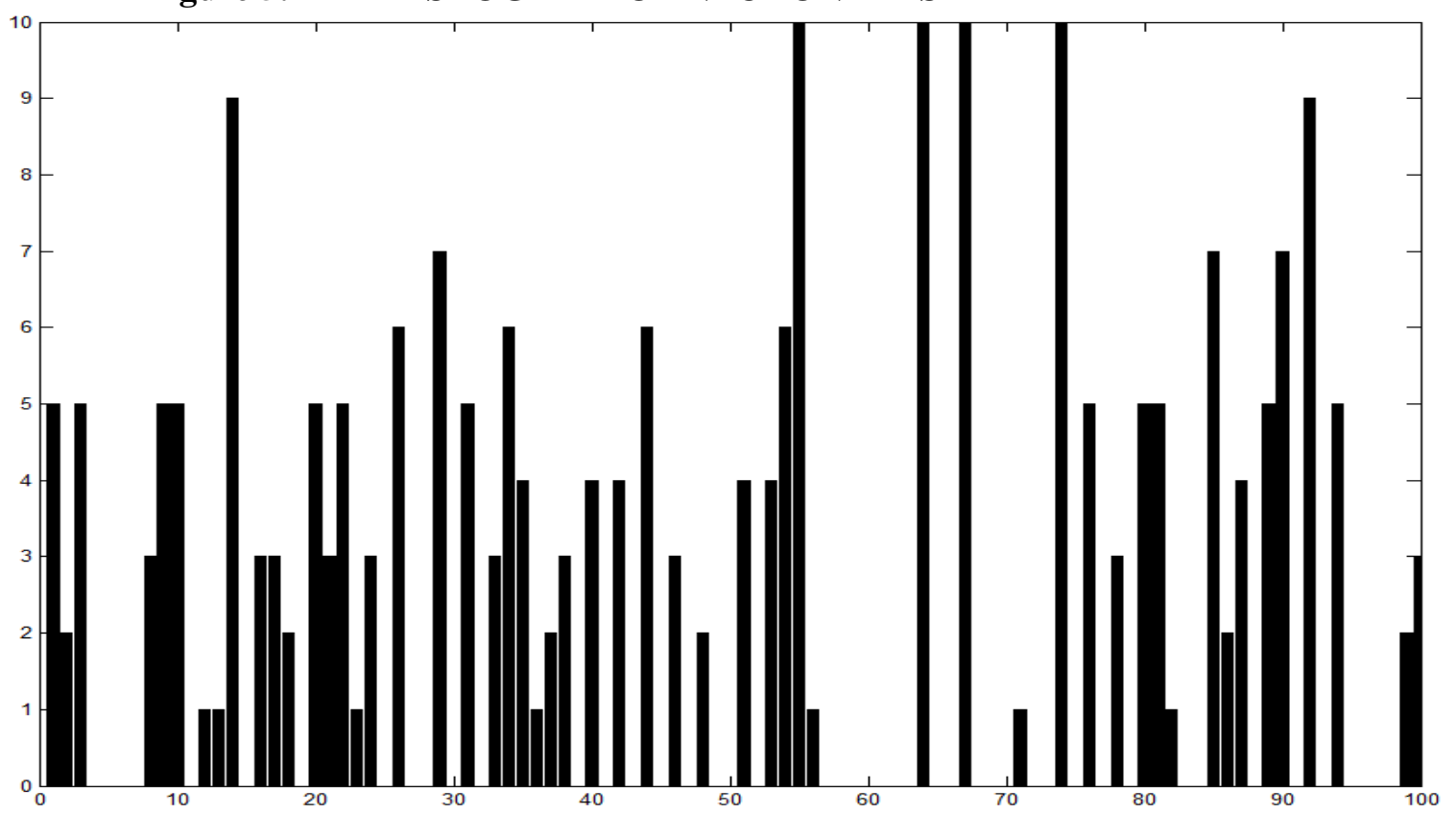

By using a hierarchical procedure, we have also drawn the histogram of neuron hits. Figure 5 shows the reaction of all 100 neurons to the input space of the data. We may find that our expectations have turned out to be right. The map has created natural borders separating groups of countries. These borders appear as areas of non-active neurons (empty neurons without hits). It is very interesting to note that, despite a large number of neurons (100), many of the neurons are the winning neurons for 5 or even more input vectors.

In order to additionally verify the quality of the model results, we have compared the distribution of the weight values with the related distribution of the variables, which form the input data space. The results are shown in Figures 6 and 7. We can observe in these figures that the distributions for the selected weights (histograms are shown in Figure 6) very successfully imitate the distribution of the values of the related variables (see histograms in Figure 7). This may be interpreted as a very good adaptation of the map to the input data space.

Figure 6:HISTOGRAM OF WEIGHT VALUES FOR EACH VARIABLE 
A Map of the European Insurance Sector - Are There any Borders?
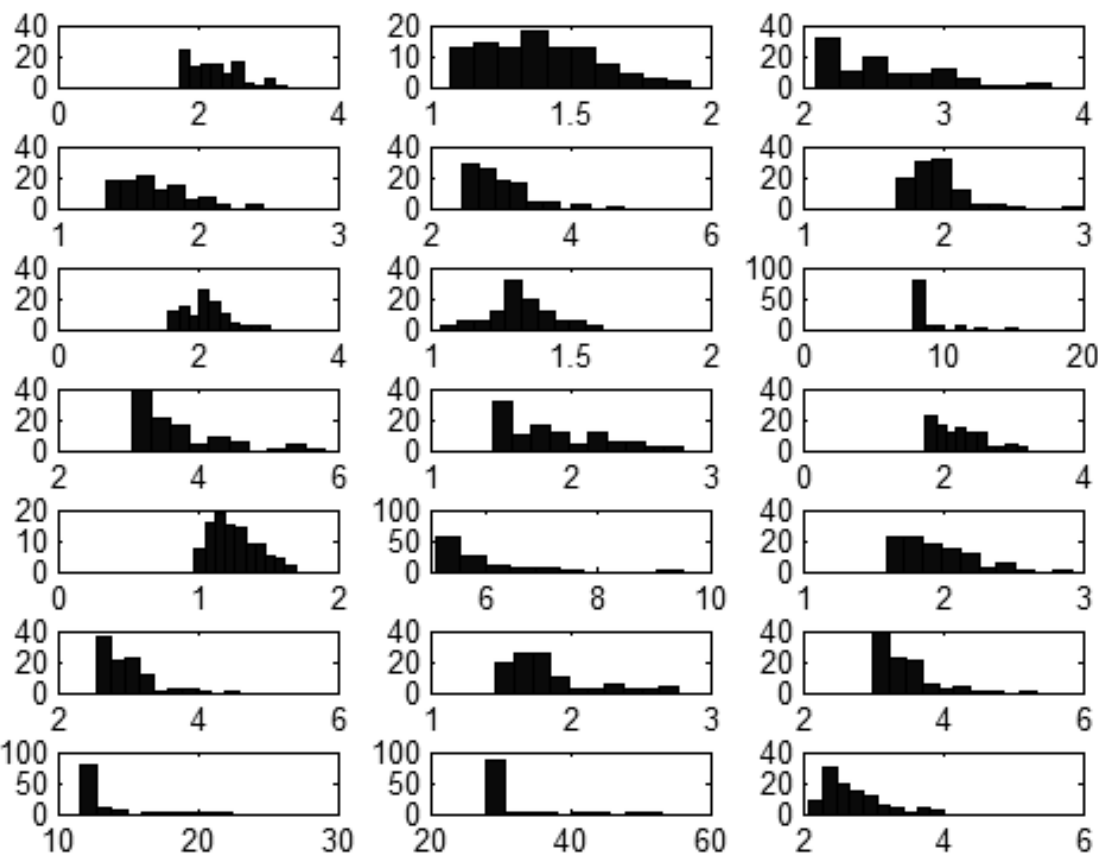

Figure 7: $\quad$ HISTOGRAM OF VARIABLES
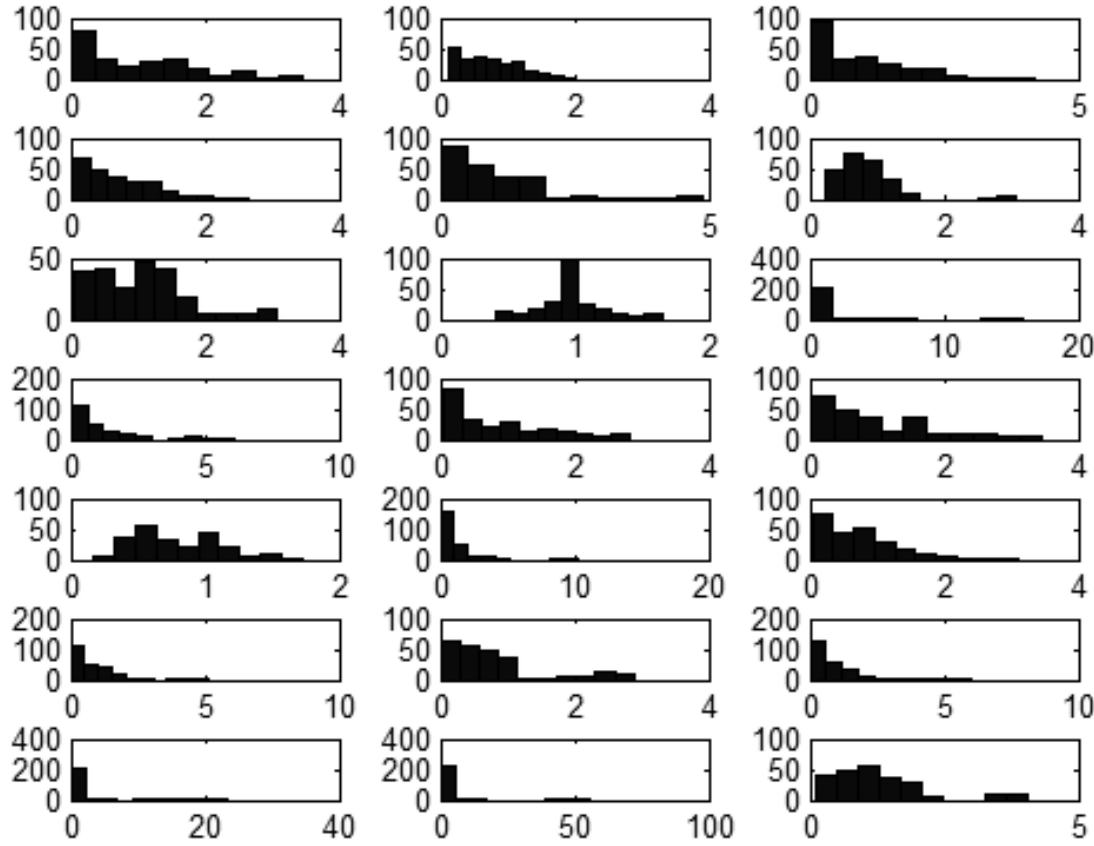

5. Discussion 
Timotej Jagric, Stefan Bojnec, Vita Jagric

The insurance market in Europe is an important part of the European financial industry. In the future its significance may become even larger, due to the ageing population and pension system reforms in the majority of the analysed countries.

In this study we analysed the dynamics of the homogeneity of the national insurance markets of $23 \mathrm{EU}$ and non-EU counties. Our results show that there are two groups of countries that differ substantially from each other, and there are two additional groups in the area in-between. Our results also revealed that despite the EU integration process, there should be some other factors that heavily influence insurance industry properties and their relative position within the European insurance market when analysed on a topographic map.

Due to differences in economic performance in Europe, the European Commission (2014, p. 53) sees the risk of further market fragmentation, as market fragmentation has already taken place. These risks may impact business models and strategies that insurance companies use (European Commission 2014, p. 53). Our results support these fears. In our dynamic topology, the insurance market seems to remain clustered and in the analysed period does not exhibit any important patterns for closing the gap. The way towards an effective single market for the insurance industry depends upon the further intensification of EU integration and is, importantly, supported by the efforts of EIOPA (see EIOPA 2015, p. 19 and onwards).

\section{Conclusion}

This paper contributes to the dynamic analysis of the European insurance market via a developed and applied neural network modelling approach and dynamic macro topology. The set hypothesis on the homogeneity and convergence of the EU insurance industry is clearly rejected. The EU insurance market has remained fragmented and dynamic, so that a single uniform pattern in development has not been identified. Instead, different patterns in development were observed. However, the set hypothesis on the divergence of the non-EU insurance markets cannot be rejected as these markets have remained dispersed among three different EU clusters.

The results clearly suggest three primarily striking findings. First, the European insurance market is far from being integrated and no prevailing mainstream cluster of the EU insurance market could be identified. Second, the mixed and heterogeneous results for the European insurance market indicates that there are more countries' clusters and that these clusters are not stable over time. Except for a smaller group of EU countries, these in and out switches from the clusters make the clusters dynamically unstable. Finally, there is no clear intention that the nonEU insurance markets are either moving closer towards non-EU countries' insurance market clusters, or moving closer to a possible prevailing cluster of EU insurance markets. From an EU integration perspective, these findings are worrying, but from the perspective of the non-EU insurance market, this might be a rational option. This result might imply that the EU insurance market has in the analysed period failed to strengthen its integration process and to become attractive 
A Map of the European Insurance Sector - Are There any Borders?

for newcomers from the non-EU insurance industry to converge closer to the EU integration process.

Further research: a further break-down of the identified main clusters of the EU and non-EU insurance markets into more sub-clusters to study the similarities, differences and stability of these sub-clusters. The neural networks approach and dynamic topology could be developed, applied and compared at a micro-insurance company level and not only at a macro-country level.

\section{ACKNOWLEDGEMENTS}

The authors acknowledge the financial support from the Slovenian Research Agency (research core funding No. P5-0027).

\section{REFERENCES}

[1] Adam, K., Jappelli, T., Menichini, A., Padula, M. and Pagano, M. (2002), Analyse, Compare, and Apply Alternative Indicators and Monitoring Methodologies to Measure the Evolution of Capital Market Integration in the European Union. Salermo: Centre for Studies in Economics and Finance (CSEF), Department of Economics and Statistics, University of Salermo;

[2] Apergis, N., Gabrielsen, A., Payne, J. and Zagaglia, P. (2012), Testing for Convergence in the European Insurance Sector: A Non-Linear Factor Approach. Asian Journal of Finance and Accounting, 4 (2), 1-17;

[3] Babecký, J., Komárek, L. and Komárková, Z. (2010), Financial Integration at Times of Financial Instability. CNB Working Paper Series, No. 9;

[4] Baele, L., Ferrando, A., Hördahl, P., Krylova, E. and Monnet, C. (2004), Measuring Financial Integration in the Euro Area. ECB Occasional Paper Series, No. 14;

[5] Baltzer, M., Cappiello, L., De Santis, R.A. and Manganelli, S. (2008), Measuring Financial Integration in new EU Member States. ECB Occasional Paper Series, No. 81;

[6] Bernat, T. and Grundey, D. (2007), Insurance Market Maturity: A

Comparative Study in Poland and Lithuania. Technological and Economic Development of Economy, 13 (3), 184-190;

[7] Clark, M. (2009), Uncertainties, Challenges and Opportunities of Global Insurance Regulatory Convergence. Risk Management, 15, 49-51;

[8] Cummins, J. D., Rubio-Misas, M., Vencappa, D. (2017), Competition, Efficiency and Soundness in European Life Insurance Markets. Journal of Financial Stability, 28, 66-78;

[9] European Central Bank (2005), Indicators of financial integration in the Euro area. Available at:

http://www.ecb.europa.eu/pub/pdf/other/indicatorsfinancialintegration200509en.pd f; 
Timotej Jagric, Stefan Bojnec, Vita Jagric

$\overline{\text { [10] European Central Bank (2014), Financial integration in Europe. Available }}$ at:

http://www.ecb.europa.eu/pub/pdf/other/financialintegrationineurope201404en.pdf

[11] European Commission (2009), European Financial Integration Report

2009. Commission Staff Working Document. Available at

http://ec.europa.eu/internal_market/economic

_analysis/reports/index_en.htm\#maincontentSec2;

[12] European Commission (2014), European Financial Stability and

Integration Report 2013. Available at:

http://ec.europa.eu/internal_market/economic_analysis/docs/efsir/140428-efsir-

2013 en.pdf;

[13] European Insurance and Occupational Pensions Authority (2015),

Annual Report 2014. Available at:

https://eiopa.europa.eu/Publications/Reports/EIOPA_ANNUAL_REPORT_2014.p

df ;

[14] Fenn, P., Vencappa, D., Diacon, S., Klumpes, P. and O'Brien, C. (2008),

Market Structure and the Efficiency of European Insurance Companies: A

Stochastic Frontier Analysis. Journal of Banking and Finance, 32, 1, 86-100;

[15] Handschke, J. (ed) (2004), Internet and Insurance Contracts in Poland -

Report (in Polish). Department of Insurance, Academy of Economics in Poznan;

[16] Insurance Europe (2014a), Statistical Series. Available at

http://www.insuranceeurope.eu/facts-figures/statistical-series;

[17] Insurance Europe (2014b), European Insurance in Figures. Statistics

$\mathrm{N}^{\circ} 48$, February 2014;

[18] Jagric, T. (2013), Kako izboljšati merjenje bančne integracije v evrskem območju. Bančni vestnik, 62 (6), 36-40;

[19] Jagric, T., Bojnec, S. and Jagric, V. (2015), Optimized Spiral Spherical

Self-Organizing Map Approach to Sector Analysis - the Case of Banking. Expert Systems with Applications, 42 (13), 5531-5540;

[20] Jagric, T. and Zunko, M. (2013), Neural Network World: Optimized Spiral Spherical SOM (OSS-SOM). Neural Network World, 23 (5), 411-426;

[21] Kasman, A. and Turgutlu, E. (2011), Performance of European Insurance

Firms in the Single Insurance Market. International Review of Applied

Economics, 25 (3), 363-378;

[22] Lane, P.R. (2008), EMU and Financial Integration. Institute for

International Integration Studies. IIIS Discussion Paper, No. 272;

[23] Müller-Reichart, M. (2005), The EU Insurance Industry: Are we Heading

for an Ideal Single Financial Services Market?. Geneva Papers on Risk and

Insurance, 30 (2), 285-295;

[24] Sangowski, T. (2002), Polish Insurance Market - Situational Analysis and

Future Directions. In Insurance in the Market Economy, Sangowski T. (ed),

Branta, Bydgoszcz;

[25] Sulkowska W (ed) (2000), Barriers in Developing the Polish Insurance

Market. Zamykacze, Kraków. 